\title{
Reforma judiciária e democratização na América Latina $^{1}$
}

Revista do

Serviço

Público

Ano 48

Número 1

Jan-Abr 1997

\author{
Hugo Frühling E.
}

\section{Introdução}

A teoria democrática baseia-se na noção de que os indivíduos deveriam exercer um certo grau de autonomia, que é assegurada pela possibilidade de participar na governança da sua comunidade, por meio da escolha livre de seus representantes. O governo que emerge da vontade popular é um governo sujeito a limites, impostos por controles nos seus procedimentos e pelo respeito aos direitos constitucionais. $^{2}$

Uma das principais limitações do poder governamental é o que distingue a administração da decisão judicial. A autoridade final que determina o real sentido de uma lei está depositada no arbítrio do juiz, que deve ser totalmente independente do administrador, assegurando assim uma interpretação impessoal das leis. ${ }^{3}$

A distinção entre administradores e juízes não está associada somente a regimes democráticos, já que ela sobreviveu mesmo a aqueles mais opressores. Entretanto, ela é uma condição necessária, embora insuficiente, para a democracia, já que os juízes têm um papel destacado na manutenção dos direitos constitucionais e liberdades. ${ }^{4}$

Juristas de toda a América Latina estariam de acordo com a afirmação de que um sistema judiciário independente e efetivo é o principal atributo de uma sociedade democrática. Ainda assim, os problemas enfrentados pela justiça e pelas instituições do Estado que se encarregam de administrar a justiça são profundos e comuns em

Hugo

Frühling E.

é doutor em direito pela Universidade de Harvard e é professor do Instituto de Ciências Políticas da Universidade do Chile

Tradução de Maria Christiana Ervilha 
toda a região. A maioria dos sistemas judiciários existentes é incapaz de suprir esta necessidade. Com raras exceções, eles ainda não conseguiram garantir o exercício pleno dos direitos constitucionais; foram vítimas de manipulações políticas de governos democráticos e militares; não tiveram acesso ao financiamento necessário para exercer suas funções, e a posição política dos juízes com relação ao governo foi sempre muito fraca. ${ }^{5}$ Além disto, atrasos e corrupção são características bastante comuns nos Poderes Judiciários latinoamericanos, e o sistema jurídico nem sempre é acessível a todos os que desejam justiça.

A reforma judiciária depende, em grande parte, do funcionamento do sistema democrático. No entanto, alguns autores têm afirmado que a violência política esteve sempre presente na evolução das sociedades latino-americanas e é resultado do constante retorno do autoritarismo e da repressão na permanência da tradição cultural dominante, onde freqüentemente os setores importantes da elite opõem-se à democracia, e pela fragilidade do pluralismo político. ${ }^{6}$ Assim, pergunta-se se o ideal democrático do princípio do Direito pode, de fato, estabelecer-se neste contexto social e cultural.

Segundo nosso ponto de vista, é verdade que uma cultura política autoritária encontra-se profundamente enraizada na América Latina. No entanto, ela estabeleceu-se em alguns países, enquanto outros, ao contrário, gozaram de longos períodos de estabilidade democrática. Alguns acontecimentos promissores, vividos recentemente na região, tais como o aumento do número de governos civis eleitos pela via democrática, ou o crescente consenso em torno de políticas econômicas, propiciam um ambiente mais favorável ao fortalecimento das instituições democráticas que no passado. Esta mudança, no contexto político, criou condições para uma nova visão, preocupada em aperfeiçoar o funcionamento dos sistemas legal e jurídico. Porém, estes esforços pela reforma legal ainda enfrentam enormes obstáculos que serão analisados neste artigo.

O presente artigo examina os esforços atuais em aperfeiçoar o Judiciário na América Latina. Ele explora os fatores que vêm favorecendo este movimento, como também seu possível impacto no fortalecimento dos princípios do direito e no crescente sentimento de responsabilidade das autoridades políticas. Finalmente, ele pressupõe que estas mudanças são somente o início de um longo processo, cujo sucesso não está absolutamente assegurado.

A primeira parte deste artigo analisa os problemas enfrentados pelos sistemas legais e jurídicos latino-americanos desde a década de 60, e sua ligação com o desenvolvimento econômico e com a garantia do direito à justiça. Ele fornece um breve resumo das 
tentativas reformistas de modificar a cultura legal dominante na América do Sul, analisando o movimento pela lei e pelo desenvolvimento, instaurado entre o final dos anos 60 e o início da década de 70 no continente sul-americano. A segunda parte descreve os problemas enfrentados pelo Judiciário, bem como os esforços pela reforma dos sistemas jurídicos do hemisfério, iniciados nos anos 80 . A terceira parte analisa os obstáculos encontrados por tais esforços, sugerindo que a mudança seja gradual e cheia de contradições.

\section{As tentativas de reformas sociais-legais durante as décadas de 60 e 70}

O avanço da democratização na América Latina exige mudanças sociais e legais profundas que irão garantir o respeito pelos direitos humanos, o acesso à justiça e o sentimento de responsabilidade de autoridades civis e militares. Conforme sustentado por Teresa P.R. Caldeira e James Holston em seus escritos, os princípios do direito, o acesso à justiça e a proteção dos direitos civis não são produtos automáticos da institucionalização de políticas competitivas. $^{7}$

Para avaliar o impacto das reformas legais e políticas que estão sendo implantadas atualmente, bem como suas chances de sucesso, farei uma comparação entre as tentativas de reforma feitas nos anos 60 e 70 e aquelas em curso atualmente. A comparação começa pela descrição dos temas aos quais foram atingidos por tais reformas, as forças que as apoiavam e as razões dos seus sucessos ou fracassos.

\subsection{A crise do Direito e o ideal de modernização}

As políticas dos países latino-americanos mais desenvolvidos têm mostrado, desde 1940, uma preocupação com a eqüidade social. No entanto, somente algumas das formas mais flagrantes de ineqüidade social foram atingidas por meio de intervenção governamental no mercado. Isto propiciou uma situação de polarização política e inquietação. No final dos anos 50, os sintomas de uma doença social já existiam, à medida que problemas como pobreza, inflação e dependência de matéria-prima para exportações não conseguiam ser solucionados.

Muitos cientistas sociais e líderes políticos definiram o processo de subdesenvolvimento como resultado da coexistência de tradições e instituições ocidentais com outras tradicionais. No Direito, 
apresentava-se uma justaposição de diferentes tipos de utilização da norma legal. Havia uma ordem legal central que imitava modelos estrangeiros, mas havia também um sistema informal de costumes, valores e códigos informais de procedimento que influenciavam a operação daquela ordem legal, tornando-a ineficaz. ${ }^{8}$

Ainda mais importante que este hiato entre Direito e a realidade era o crescimento de uma norma que regulava a economia, e que mostrava pouco interesse em estabelecer métodos de racionalização legal, criando conflitos entre as normas interpretadas por advogados e as pelos orgãos reguladores.

Esta contradição estimulou a consciência de que o sistema legal estava atravessando uma crise, ou seja, de que necessitava de reformas substanciais para sustentar o crescimento e a eqüidade social, e isto não se resolvia apenas com pequenas atualizações em algumas áreas específicas do Direito. ${ }^{9}$

No Chile, Eduardo Novoa insistiu na noção de que existia uma crise no sistema legal, e que a crise resultava da falta de harmonia entre os diferentes componentes do sistema. Novoa declarou que a nova regra econômica do Estado havia levado à emergência de um Direito cujos princípios contradiziam aqueles contidos nos códigos individualistas e tradicionais do século XIX. ${ }^{10}$ Ele achava que a falta de preocupação com a evolução do direito público demonstrada pelos juristas era a conseqüência de um ensino excessivamente voltado para o direito privado. Os advogados e especialmente os juízes estavam, assim, mal preparados para sistematizar e interpretar a legislação que veio a vigir após os anos 30 , ou para lidar com as novas necessidades coletivas. ${ }^{11}$

A percepção de que o sistema legal estava confrontando uma crise envolvia vários elementos. $\mathrm{O}$ primeiro era a noção de que havia um crescente abismo entre o direito dos livros e o direito da vida real. A realidade em vários países era que o direito formal vinha sendo totalmente desrespeitado, fato que punha em questão a validade das regras feitas pelo próprio Estado como instrumentos de desenvolvimento econômico. O segundo era a existência de contradições sérias entre o sistema legal central, inspirado pelo movimento europeu de codificação do século XIX, e as regulamentações realizadas a partir de 1930 . O terceiro elemento era o grande descontentamento com o sistema educacional latino-americano de formação em direito. Durante os anos 60 e início dos anos 70, a região realizou movimentos significativos em favor da reforma do estudo do Direito, em busca da preparação de advogados e juízes melhor preparados para lidar com a mudança social global. 
O ideal de planejamento social, associado a políticas de modernização, criou uma nova demanda por habilidades específicas tais como planejamento, contabilidade, criação de projetos de desenvolvimento, etc. Estes conhecimentos técnicos já haviam sido dominados por economistas e sociólogos, mas ainda não eram ensinados aos alunos de Direito. ${ }^{12}$

O movimento, em favor da reforma do estudo do Direito na América Latina, veio das próprias escolas de direito da própria região, tendo sido apoiado por professores relativamente jovens e alunos. Assim, conferências de escolas de direito latino-americanas, que tratavam da necessidade de promover-se um ensino ativo e prático, assim como o aprendizado dos fatos econômicos e sociais em áreas reguladas pelo sistema legal, tiveram lugar em 1959, 1961, 1963, 1964 e 1965, em vários países da região. ${ }^{13}$

Outra fonte de apoio às mudanças veio do Movimento Direito e Desenvolvimento, um resultado da assistência americana ao Terceiro Mundo. Instituições norte-americanas, como escolas de direito, fundações e agências governamentais voltadas ao Terceiro Mundo, envolveram-se neste esforço. ${ }^{14}$ No tocante à América Latina, o esforço consistia em promover a reforma do ensino do Direito e em desenvolver uma pesquisa sobre o papel do Direito no desenvolvimento.

Estudantes de Direito e desenvolvimento viram o modelo do advogado americano como uma fonte de solução particularmente útil para países em desenvolvimento. ${ }^{15}$ Conseqüentemente, eles passaram a considerar que advogados e juízes latino-americanos deveriam assumir um papel modernizador, capaz de lidar com novos problemas, visualizando soluções dentro dos limites legais, e fazendo com que essas soluções fossem aplicadas.

Este ponto de vista, por sua vez, encorajava o uso do método de estudo de caso para confrontar o aluno com os vários problemas que encontraria em sua vida profissiona ${ }^{16}$. A metodologia de ensino enfocava o modelo que considera o advogado e o juiz como engenheiros sociais, promovendo uma concepção instrumental do Direito aberta a várias interpretações, que servia de instrumento para regulamentar as novas relações e os processos sociais.

Vários programas de apoio à pesquisa e capacitação de professores de Direito foram executados na Costa Rica, Brasil, Chile, Colômbia e Peru. Na Colômbia, formou-se a ARED (Associación para la Reforma de la Enseñanza del Derecho), e no Chile surgiu o Instituto de Docencia e Investigaciones Jurídicas. No final de 1972, a ARED já estava decadente, e o Instituto de Docência desapareceu logo após o golpe de Estado de 1973. 
O movimento pela reforma, a partir das escolas de Direito, criara um novo interesse pela análise do papel do Direito na sociedade. No entanto, ele perdeu sua importância em poucos anos, deixando muito poucos efeitos duradouros. ${ }^{17}$

Gostaria de ressaltar alguns pontos que podem explicar tal fracasso. Primeiramente, o contexto político em alguns dos países onde o programa foi lançado não era favorável à experiência, visto que Chile, Brasil, Peru, Argentina e Uruguai viveram mudanças políticas e uma repressão durante a segunda metade da década de 70 , encerrando assim todas as tentativas de mudança social nas quais o Direito poderia exercer um papel significativo. Em segundo lugar, estes esforços de reforma encontravam grande resistência por parte dos acadêmicos tradicionais das escolas de Direito. Finalmente, é questionável pensar que meras modificações no ensino do Direito poderiam ter modificado a ideologia interna e a perspectiva dos advogados e juízes, cujos valores e práticas eram também moldados por fatores como mercado profissional, estrutura interna de poder do Judiciário, e posição do mesmo dentro do sistema político.

\subsection{O movimento de reforma legal e o judiciário}

O movimento de reforma legal inspirou os primeiros estudos sócio-legais do Judiciário latino-americano. ${ }^{18}$ A maior parte dos textos dos seguidores do movimento que se referiam aos juízes ressaltava o conteúdo ideológico de suas interpretações da lei, distinguindo aqueles juízes que mostravam alguma abordagem inovadora da interpretação da norma daqueles estritamente obedientes à análise textual da lei. ${ }^{19}$ No entanto, apesar de poucas exceções, foi pequeno o enfoque dado ao Judiciário como organização, os princípios e regras que regiam o exercício da autoridade no seu interior, sua independência do Poder Executivo, suas relações com políticos ou outros aspectos institucionais que definem a ideologia dos juízes e sua abordagem da lei.

Estritamente falando, os defensores da reforma dos anos 60 e 70 esforçaram-se pouco em trabalhar com os próprios juízes, visto que eles haviam definido os professores de Direito como seu públicoalvo. ${ }^{20}$ Assim, e na maioria das vezes, o impacto de suas críticas sobre o ensino legal tradicional não foi além da comunidade acadêmica de Direito.

Na década de 80 , as políticas públicas que visavam à garantia de um sistema jurídico independente, imparcial e efetivo haviam se tornado o foco do debate intelectual e político. 
O destaque que a reforma judiciária alcançou na agenda pública deve-se, certamente, ao fato de que os eventos históricos que marcaram os anos 70 e 80 reforçaram muitos dos problemas que o Judiciário vinha há tempos enfrentando. A qualidade da justiça diminuía à medida que a repressão intensificava-se, e o acesso eqüitativo ao sistema de justiça deteriorava-se mais e mais. A preocupação com a reforma do Judiciário também foi fruto de uma convergência de forças e causas.

\subsection{A administração dos esforços da reforma da justiça}

A transição dos governos civis democraticamente eleitos, de um lado, e a implementação de políticas de livre mercado, do outro, contribuíram para o interesse atual pela reforma do Judiciário na região.

A expansão da onda de democratização, que teve início no Equador no final dos anos 70, continuou no Peru em 1980, e dali espalhou-se para o Uruguai, Argentina, Brasil, Paraguai e América Central; criou as condições ideais para um novo interesse em aprimorar o sistema judicial, particularmente naqueles países em que tenham acontecido evidentes violações de direitos humanos sistemáticas e abusivas. O restabelecimento da norma civil estava voltado para o Judiciário como sendo o guardião contra os abusos aos direitos humanos. Como veremos, este processo não foi totalmente consistente em toda a região.

Um segundo elemento que explica a nova importância que a reforma jurídica passou a ter, na agenda política da região, foi a elevação dos padrões de violência criminal em vários países, como El Salvador, Colômbia, Brasil, Guatemala e Peru. Isto criou uma demanda pela reforma do sistema jurídico penal de forma a aumentar a capacidade de investigação e punição por parte da polícia, dos tribunais e dos promotores. Esta não é uma tarefa fácil, já que em muitos desses países a polícia tem sido um participante ativo nos atos criminosos.

Finalmente, um terceiro e mais recente fator a ser considerado é que o bom funcionamento do Judiciário era importante para o processo de reforma econômica que se instala na América Latina. Um ambiente institucional estável, formado por instituições que aplicam a lei de forma consistente e previsível, era muito importante para os investidores privados. Isto chamou a atenção para a necessidade de aprimoramento da administração dos tribunais, organizando-se programas contínuos de capacitação para juízes, e da criação de mecanismos alternativos para a solução de disputas judiciais. 
Um fator fundamental para a promoção da reforma judiciária

foi a política norte-americana de apoio aos governos que desejassem construir e reforçar as instituições democráticas. O Programa NorteAmericano de Administração da Justiça, concebido para melhorar o funcionamento dos sistemas judiciários, promotores governamentais e polícia, apoiou reuniões periódicas entre especialistas de Direito latino-americanos para discutir os problemas da justiça, avaliações dos sistemas jurídicos realizadas por consultores de Direito e administração pública, e programas de treinamento para o pessoal do Judiciário.

Nos anos seguintes, o Banco Mundial e o Banco Interamericano de Desenvolvimento (BID) também incentivaram projetos de reforma judiciária, no contexto de programas para a modernização do Estado e a promoção do desenvolvimento.

\section{Os sistemas judiciários latino-americanos}

Há uma crença, presente em toda a América Latina, e também na comunidade internacional, de que algumas das características básicas de um sistema judiciário independente, democrático e eficiente não estão presentes em muitos dos países da região. Alguns dos sintomas do mau funcionamento do Judiciário são: a) que o Judiciário tenha apoiado ou deixado de combater políticas repressivas das forças de segurança; b) que a justiça criminal esteja presa a um processo criminal que não é eficiente na investigação do crime comum; c) que o julgamento sofra atrasos crescentes e incertezas associadas à espera pela decisão judicial dos casos; ${ }^{21}$ d) que a corrupção e desconfiança pública no Judiciário esteja atingindo níveis muito altos.

\subsection{O Judiciário e os direitos humanos}

Durante a década de 70 e parte da década de 80, a América Latina assistiu ao nascimento da violência política, como também a uma deterioração da situação dos direitos humanos. A repressão militar alcançou níveis sem precedentes no Chile, Argentina, Brasil, Colômbia, Guatemala e El Salvador.

No Chile, após a tomada de poder pelos militares em 1973, a Corte Suprema aceitou que parte de seus poderes fossem transferidos para tribunais militares, e mostrou grande deferência ante o Estado autoritário, recusando-se a desafiar os poderes legais de emergência invocados pelo governo. Apesar de provas conclusivas da existência de abusos contra os direitos humanos, os 
tribunais postergavam as investigações de desaparecimentos solicitadas pela Igreja e por parentes das vítimas. ${ }^{22}$ Somente durante os últimos anos da década de 80 , alguns juízes mostraram maior independência para processar casos de violações dos direitos humanos. ${ }^{23}$

Muitos analistas vêem estas atitudes como raízes da era prégolpe, com o argumento de que ela deveu-se a dois fatores: primeiro, ao alto nível de conflito existente entre o Presidente Allende (19701973) e a Corte Suprema, que exacerbou o julgamento conservador. Segundo, ao fato de que os juízes operavam com autonomia corporativista, e não renovaram seu pensamento legal seguindo a evolução social e política. Assim, abdicaram do seu dever de interpretar e aplicar a lei na defesa dos princípios democráticos. ${ }^{24}$

Uma conseqüência da atitude dos tribunais com relação aos direitos humanos é a percepção negativa por parte da opinião pública. Uma pesquisa recente entre a população urbana pobre no Chile mostrou que $46,5 \%$ dos entrevistados achavam o Poder Judiciário ruim ou muito ruim, $43,5 \%$ o consideravam medíocre (regular), e somente $9,1 \%$ declararam-no bom ou muito bom. ${ }^{25}$

A Guatemala apresenta um caso ainda mais extremo, onde o Judiciário foi acusado de permanecer apático diante das décadas de repressão militar. Com muito poucas exceções, o Judiciário absteve-se de atuar em defesa dos direitos humanos durante os regimes militares nos anos $80 .{ }^{26}$ Neste mesmo período, sua legitimidade de julgar disputas legais em outras áreas do Direito foi consideravelmente enfraquecida, tornando-o virtualmente ineficaz. ${ }^{27}$

Como indicam Teresa P.R. Caldeira e James Holston em seu estudo sobre o Brasil, a desligitamação do sistema de justiça no país deu-se, em parte, porque o sistema judiciário não é considerado pela classe trabalhadora como fonte confiável para defendê-la dos abusos da polícia ou das outras autoridades do poder público. ${ }^{28}$

Assim, a sensação de que o Judiciário não tem sido um árduo defensor dos direitos humanos é amplamente compartilhada por sociedades latino-americanas, fato que enfraquece sua legitimidade e a aplicação da lei.

\subsection{O sistema de justiça penal e suas respostas ao crime comum}

Desde a década passada, o crime comum foi expressado pela violência, pelo crime de rua, pelo narcotráfico e pela corrupção, tendo se tornado um assunto importante em quase todos os países da América Latina. As fontes deste fenômeno são muitas. 
O crime comum evoluiu depois do final da guerra civil em El Salvador e Nicarágua, graças à dispensa de militares e guerrilheiros que não estavam preparados para a vida civil e começaram a ganhar a vida por meio de atos criminosos. ${ }^{29}$

O acordo de paz entre o governo de El Salvador e a FMLN (Frente Farabundo Martí para la Liberación Nacional) previa reformas judiciais, como também a organização de uma nova força policial para a proteção dos direitos humanos e a investigação de ações criminais.

Em outros casos, como a Colômbia no final dos anos 80, a própria ordem social esteve ameaçada pela evolução do crime e pelas mudanças no tipo de criminalidade, que se tornou mais organizada e violenta. O sistema de justiça criminal era simplesmente incapaz de fazer frente à situação. Em junho de 1982, havia 1.397.800 casos pendentes nos tribunais, que representavam um aumento de $85 \%$ em 11 anos. ${ }^{30}$

Mesmo no Chile, onde o crime violento era menos freqüente, a grande preocupação da população, de acordo com diferentes pesquisas, era o aumento do crime comum nas ruas, e também do aumento do tráfico e do consumo de drogas. Em 1989, os Carabineros registraram uma taxa de 1.556 crimes por 100.000 habitantes; em 1990 foram registrados 1.681 , e em 1991 a taxa de crimes havia aumentado para 1.711. O mais preocupante era o aumento das ocorrências de assaltos a mão armada registradas na polícia. ${ }^{31}$

Muitos sistemas de justiça da América Latina são incapazes de confrontar a situação do crime, por enfrentarem, todos, dificuldades comuns: os executores dos sistemas de justiça são dependentes dos militares, que detêm os recursos e a motivação para conduzir as investigações dos casos criminais. Há também um problema de falta de competência técnica nas forças policiais ${ }^{32}$. Os mecanismos de fiscalização da aplicação da lei são inadequados, seja pela inexistência de uma procuradoria de justiça, como no Chile, ou pelo seu pequeno impacto no exercício da justiça. Por último, o processo penal é formal, escrito, praticamente sem oportunidade de declarações verbais, confronto de testemunhas ou outros procedimentos.

Em resposta a esta situação, muitos países, como Guatemala, Peru e Equador, prepararam projetos de novos códigos de processos criminais, e um movimento similar está acontecendo no Chile atualmente. Tais códigos estão introduzindo procedimentos orais e contestatórios no sistema de justiça penal.

São duas as razões de ser desta proposta: julgamentos públicos são defendidos por serem mais efetivos, e protegerem os direitos do acusado. 
Julgamentos públicos e procedimentos contestatórios são mais rápidos, e garantem a participação direta do juiz em procedimentos que, na América Latina, são geralmente delegados a oficiais administrativos dos tribunais. A publicidade do julgamento reforça o sentimento de responsabilidade dos juízes, e o próprio processo passa a ser mais eficiente no controle e descoberta de falsas testemunhas, já que permite a acareação. ${ }^{33}$

Ainda mais importante, o sistema contestatório garante a realização de um julgamento real, onde o acusado tenha pleno acesso às evidências obtidas pela polícia, e os direitos integrais da defesa sejam plenamente assegurados. ${ }^{34}$

\subsection{O sistema judiciário e a reforma econômica}

A América Latina tem experimentado uma transformação sócio-econômica importante, que afeta os valores culturais, os modelos de conflito social e político, e o papel do Estado, assim como o do Judiciário, na sociedade. ${ }^{35}$

Desde 1930, o Estado tem exercido um papel fundamental no desenvolvimento econômico da região, estabelecendo altas tarifas de importação para proteger o empresariado nacional, fixando preços, subsidiando determinados produtos, e desencorajando a produção de outros. Até certo ponto isto teve um forte impacto na regulamentação de sérios conflitos sociais e legais, resolvidos, em muitos casos, por funcionários administrativos e por políticos, sem terem chegado aos tribunais. ${ }^{36}$

Importantes disputas trabalhistas foram mediadas pelo governo, invasões de terra rapidamente transformadas em conflitos políticos, ao invés de disputas legais, e interesses difusos, como os dos consumidores, foram defendidos por órgãos reguladores. Numa sociedade deste tipo, o acesso aos órgãos administrativos era mais importante que o acesso aos tribunais. Isto é naturalmente uma generalização, pois os dados mostram que a carga de processos dos tribunais aumentou rapidamente durante este período. A maior parte dos casos, porém, lidava com números de assuntos limitados: inadimplências e processos criminais por roubo, assalto, agressão física e outros do tipo. ${ }^{37}$

As mudanças econômicas recentes tendem a reverter este quadro. Novas políticas geralmente seguem a abertura de mercados internos, a expansão do papel do mercado, a diminuição da influência da administração na alocação de benefícios econômicos para as diferentes partes, e um aumento na importância de mercados externos para produtores internos. 
Pérez Perdomo ${ }^{38}$ e Peña ${ }^{39}$ concordam que tais mudanças deverão resultar em numerosas e complexas demandas por decisões judiciais. Transações legais transnacionais mais numerosas irão necessariamente resultar em casos mais complexos julgados por tribunais, mesmo que as partes tenham incluído cláusulas arbitrárias em seus contratos. Pérez Perdomo afirma ainda que o crescimento de transações comerciais transnacionais causaram, tanto nos Estados Unidos quanto na Espanha, uma explosão de novos processos apresentados perante os tribunais ${ }^{40}$.

A emergência e o crescimento dos mercados são um processo complexo que requer o reforço dos direitos legais, de forma objetiva e consistente, e num período razoável de tempo, por instituições acessíveis às partes em conflito ${ }^{41}$. Um sistema judiciário, afetado por atrasos excessivos e por funcionários corruptos ou incompetentes, torna-se um elemento adicional de incerteza nas transações econômicas.

Infelizmente, a qualidade da justiça na região é tida como muito baixa. O último Relatório de Competitividade Mundial apresenta uma comparação entre a confiança do público nos sistemas judiciários em 35 países. Todos os países latino-americanos, com exceção do Chile, figuram no patamar dos $20 \%$ de confiança ${ }^{42}$.

A percepção de que o Judiciário não é eficiente ou honesto está refletida em pesquisas de opinião pública com a exceção da Costa Rica. No Peru, depois da intervenção do governo no sistema judiciário em 1992, 95\% dos entrevistados declararam estar de acordo com esta reorganização. Uma pesquisa realizada em agosto de $1992 \mathrm{em}$ Buenos Aires chegou aos seguintes resultados: para $23 \%$ das pessoas indagadas, o número de casos de corrupção entre juízes era excessivo, para $43 \%$ havia um número razoável de casos, para $24 \%$ os números eram baixos, e somente $2 \%$ os consideravam inexistentes ${ }^{43}$.

Os atrasos e demoras parecem estar aumentando dentro dos sistemas judiciários latino-americanos. Por exemplo, em 1993, o tempo médio para conclusão de processos nas jurisdições cíveis na Argentina, Equador e Venezuela eram 2.5, 1.9 e 2.4 anos respectivamente ${ }^{44}$.

Concluindo, o crescimento da economia de mercado é uma fonte adicional de pressão para a realização da reforma das instituições judiciais.

\subsection{Os atores que apóiam a reforma judiciária}

A preocupação atual com a reforma do sistema judiciário em muitos países da região tem sido apoiada por atores tanto internos quanto internacionais. 


\subsubsection{Apoio internacional}

O Apoio Internacional pela Reforma Judiciária na América Latina originou-se nos Estados Unidos. Apesar da desconfiança inicial na assistência ao desenvolvimento democrático, a administração Reagan inaugurou uma série de projetos de desenvolvimento político no início dos anos 80. Estes projetos incluíam um extenso programa de assistência judiciária, que se tornou o principal beneficiário dos recursos para desenvolvimento. ${ }^{45}$

Este programa foi executado pelo AID, o Departamento de Estado, o Departamento de Justiça e a USIA. O objetivo principal era prestar assistência a tribunais, juízes, promotores e oficiais de justiça em toda a América Latina, visando à melhoria da administração da justiça, em particular da justiça penal. ${ }^{46} \mathrm{Um}$ componente secundário do programa era a assistência a forças policiais na região, para desenvolver sua capacidade de investigação criminal.

No início, o programa concentrou-se em El Salvador, como uma forma de resposta imediata às denúncias feitas pelos democratas do Congresso americano contra o governo Reagan, que não pressionava El Salvador pelo julgamento de criminosos de extrema direita. O Departamento de Estado respondeu às acusações com a idéia de um programa de assistência ao Judiciário daquele país. ${ }^{47}$

O crescimento das atividades do AID no campo da reforma da justiça na América Central foi objeto de críticas, visto que muitos observadores, dentro ou fora dos Estados Unidos, perguntavam se alguns dos governos assistidos eram realmente democráticos, e estariam mesmo dispostos a processar as violações aos direitos humanos e a estabelecer os princípios do Direito. ${ }^{48}$ De fato, a assistência técnica prestada aos sistemas judiciários que se esquivassem de qualquer resposta séria ao terror governamental, e a forças policiais que cometeram muitos dos crimes que deveriam investigar, estava fadada ao fracasso. ${ }^{49}$

No entanto, uma vez assinado o acordo de paz em El Salvador, e estando a nova força de polícia estabelecida, o debate sobre o programa diminuiu. Já no governo do Presidente Bush, o Programa de Administração da Justiça na América Latina aumentou, chegando a um orçamento aproximado de 40 milhões de dólares por ano. A ênfase aos projetos regionais era cada vez menor, sendo substituída por acordos bilaterais que envolviam assistência a Ministérios de Justiça, tribunais e organizações não-governamentais dedicadas à reforma judiciária. ${ }^{50}$ 
Em 1985, o AID lançou o Projeto de Administração Regional da Justiça, com sede em Costa Rica, no Instituto das Nações Unidas para a Prevenção do Crime e Tratamento dos Infratores (ILANUD). O ILANUD ofereceu assistência a sistemas judiciários de toda a América Central, incluindo cursos de capacitação para juízes, e assistência técnica para temas como administração judiciária, gestão de casos e informações legais.

Em 1986, foi estabelecido um financiamento para apoiar programas na Guatemala, Bolívia, Colômbia, Peru, Equador e Venezuela. Os recursos eram fornecidos para programas de acompanhamento e avaliação do setor judiciário, pesquisa e treinamento, doações a organizações latino-americanas, com sede nos Estados Unidos, entre outras atividades. ${ }^{51}$

O novo programa apresentava distinções com relação ao movimento pelo direito e desenvolvimento dos anos 60 e 70 . Ele dirigia-se a instituições governamentais, basicamente ao Judiciário. O setor não-governamental era convidado a prestar assistência técnica, mas não era alvo do programa. ${ }^{52}$

Como consequiência desta nova abordagem, um dos temas do programa de reforma judiciária foi a melhoria da capacidade administrativa do sistema de tribunais em resolver o acúmulo de processos, manter um sistema estatístico confiável para planejar respostas adequadas ao crescente fluxo de casos, e ser capaz de manter bases de dados sobre a evolução dos casos. O raciocínio por trás desta preocupação com a gestão administrativa era que mudanças substanciais no Direito não poderiam ser sustentadas por uma estrutura administrativa ineficiente. ${ }^{53}$

A experiência colombiana parece sugerir que algumas das modificações introduzidas no sistema secretarial e administrativo dos tribunais resultaram no aumento da capacidade de lidar com os casos, mesmo com um reduzido número de auxiliares administrativos. ${ }^{54}$

Um segundo aspecto enfatizado pelo programa era a institucionalização do treinamento para magistrados e pessoal administrativo. Mesmo que não tenha sido pregado nenhum modelo de capacitação específico, um componente essencial era o ensino das aptidões administrativas necessárias para o bom funcionamento da máquina administrativa dos tribunais. ${ }^{55}$

Finalmente, ainda no contexto dos programas de reforma judiciária, aumentou-se o interesse na criação de métodos alternativos para a solução de conflitos fora do sistema judiciário. As explicações lógicas por trás deste novo interesse eram, primeiro, a necessidade de desviar do Judiciário conflitos que poderiam ser 
resolvidos por outros métodos que não fossem o julgamento formal; e segundo, o fato de que muitos conflitos pequenos poderiam ser resolvidos de forma eficiente por outros métodos. ${ }^{56}$

Na Colômbia, como resultado da necessidade de se diminuir a sobrecarga dos tribunais, a instância para solucionar vários conflitos de ordem legal foi transferida das cortes de justiça para agências administrativas. Ao mesmo tempo, foram criados, por algumas organizações sociais, ${ }^{57}$ vários centros de conciliação e arbitragem.

Nos últimos anos a reforma do sistema de justiça também tornou-se parte da agenda de organizações multilaterais, como o Banco Mundial e o BID.

Numa palestra recente, o presidente do BID declarou que o processo de reforma econômica vivido pela América Latina exigia uma reforma do Estado. Era necessário um novo Estado, capaz de analisar, planejar e implementar novas políticas econômicas, voltadas para o mercado, mas que ao mesmo pudesse controlar e supervisionar as áreas de negócios recentemente desregulamentadas. ${ }^{58}$

De acordo com ele, tais reformas de Estado não seriam bemsucedidas caso as normas legais não fossem eficientemente aplicadas por um Judiciário independente. Uma agenda para a mudança no Judiciário dependia de que quatro aspectos principais fossem considerados. O primeiro relacionava-se com a gestão eficiente dos sistemas de tribunais. O segundo referia-se à capacitação de juízes e ao respeito às suas carreiras profissionais. O terceiro envolvia os novos temas que exigiam intervenção judicial (prevenção do crime, proteção da família, direitos da mulher, etc.). Finalmente, o quarto referia-se à relação entre o Direito e a globalização do sistema econômico, que implicava mudanças no direito econômico internacional e sua aplicação pelo sistema Judiciário. ${ }^{59}$

Seguindo esta política, o BID apoiou o desenvolvimento de mecanismos de conciliação e arbitragem para resolver disputas de financiamento e investimento estrangeiro. Ele também vem incentivando projetos voltados ao aperfeiçoamento da máquina administrativa do sistema judiciário. ${ }^{60} \mathrm{O}$ Banco Mundial também tem apoiado alguns projetos destinados a fortalecer o setor judiciário na Venezuela e na Argentina, e de apoio à capacitação judiciária no Peru.

Dois aspectos parecem explicar o novo interesse de organizações internacionais pela reforma judiciária: primeiro, a idéia de que o desenvolvimento econômico e social depende de um sistema de governo estável e legítimo, o que inclui um Judiciário independente. Segundo, a noção de que o crescimento econômico depende do estabelecimento de um sistema legal previsível e confiável. 


\subsubsection{Apoio interno}

Os esforços pela reforma judiciária estão firmemente ligados ao fortalecimento das normas civis e do governo constitucional iniciado neste hemisfério nos últimos anos. Este processo emprestou credibilidade à reforma, e significa que propostas adequadas de legislação foram submetidas aos congressos. Além disso, a democratização facilitou o caminho da cooperação internacional com aqueles países que iniciavam a transição para a norma civil.

No caso do Chile, o pacote de reforma judiciária, apresentada pelo governo Aylwin ao Congresso, baseava-se na visão implícita de que os tribunais haviam feito muito pouco para investigar as violações aos direitos humanos durante o regime militar, apesar de não haverem sofrido uma intervenção política tão massiva quanto a ocorrida em vários outros países. ${ }^{61}$

A proposta de Aylwin tentava reduzir a visão corporativista e isolada da Corte Suprema através da criação de um Conselho Nacional de Justiça, com representantes da Corte Suprema, da Corte de Apelações, do Senado, do presidente e representantes de escolas de Direito. O conselho ditaria padrões para a nomeação e promoção, formularia políticas judiciárias, e seria responsável pela administração do sistema judiciário. O propósito desta reforma foi criar uma instituição plural, formada por pessoas com diferentes visões políticas e legais, e independentes do poder Executivo, que fosse encarregada de propor políticas voltadas às necessidades judiciárias do País. O novo governo também propôs uma reforma do processo penal, e o estabelecimento de uma escola judiciária, entre outros projetos. ${ }^{62} \mathrm{~A}$ proposta de criação do Conselho de Justiça foi recusada pelo Congresso, ao passo que outras, como a criação de uma escola judiciária para a capacitação de juízes, foram aprovadas após longos debates.

Apesar da Colômbia não ter vivido um governo militar, a aprovação de sua nova Constituição, em 1991, que fortaleceu o consenso no sistema político e encerrou o monopólio do poder político nas mãos dos dois partidos tradicionais, teve um impacto importante sobre a agenda reformista. ${ }^{63}$

Logo de início, a nova Constituição criava um órgão fiscalizador público, Fiscalía General de la Nación, encarregado da investigação de todos os crimes; reconhecia também a participação de autoridades administrativas, como também de leigos, na solução de disputas legais; reforçava ainda a autonomia administrativa e econômica do Poder Judiciário; e criava uma nova organização pública responsável por investigar os abusos contra os direitos humanos (Defensoría de Derechos Humanos). ${ }^{64}$ 
Os acordos de paz assinados na América Central também deram novo impulso aos ideais de reforma judiciária, visto que eles haviam despertado uma nova atenção na necessidade do estabelecimento de um sistema funcional de Direito. ${ }^{65}$

Esforços similares foram identificados em outros países da região, todos consistentes com o processo de instalação de autoridades civis que criticavam as violações de direitos humanos cometidas no passado.

A expansão da democratização também criou uma nova preocupação com a corrupção política e o sentimento de responsabilidade governamental, reforçando o movimento pela reforma judiciária na região. ${ }^{66}$

O processo político não é a única força interna que coloca a reforma do Judiciário na agenda pública atualmente. Outra força é o impacto que a economia de livre mercado e a integração econômica da América Latina junto ao mercado mundial exerce sobre as exigências feitas ao Judiciário.

A consciência destas mudanças vem impulsionando a reforma do sistema de justiça em toda a região, pois, pela primeira vez, determinados setores comerciais de países como Colômbia, Venezuela e México, estão defendendo a reforma. ${ }^{67}$ Entretanto, estes não representam, de forma alguma, a totalidade do setor comercial, visto que alguns deverão continuar beneficiando-se das práticas discricionárias do Estado.

Resumindo assim, o eleitorado da reforma jurídica vem defendendo-a como o resultado da combinação de processos de liberalização política, projetos internacionais de reformulação dos sistemas de justiça, e a integração sócio-econômica à economia global (p.14). A coalizão inclui defensores dos direitos humanos e dos princípios do Direito que perceberam a necessidade de um Judiciário independente e forte. Alguns empresários e juristas, preocupados com a fragilidade institucional do Judiciário e com a necessidade do estabelecimento de mecanismos alternativos de solução de conflitos, e um considerável número de políticos conscientes de que um sistema legal ineficiente ou corrupto é incapaz de aplicar a lei, pondo em risco a legitimidade política.

No entanto, a reforma judiciária implica custos para grupos que continuam lucrando com a presente situação. A questão, portanto, continua: que tipo de reforma será esta, e que obstáculos deverão ser superados para que ela alcance sucesso? 


\section{Os obstáculos enfrentados pelos esforços de reforma judiciária}

Algumas recentes avaliações sobre o retorno aos governos civis na região mostraram que foi o retorno a uma democracia minimalista, já que a transição para o governo eleito não eliminou os impedimentos à consolidação da democracia constitucional controlada civilmente.$^{68}$ Mesmo sendo menos pessimistas, é preciso ater-se ao fato de que, na tradição latino-americana, os poderes judiciários têm deficiências de poder constitucional, e isto não poderá mudar da noite para o dia. ${ }^{69}$

Um Judiciário mais independente, com autonomia orçamentária, deverá também encontrar a oposição de executivos e legisladores, que terão menos possibilidade de controlar as atividades judiciárias.

Assim, a construção de poderes judiciários que desejem sustentar os princípios do Direito exige algumas mudanças fundamentais na relação entre o Judiciário e o resto do sistema político. Esta mudança não é fácil de alcançar atualmente; ela passará por uma longa evolução, e também por muita reflexão e debate político.

Uma segunda consideração é que a reforma judiciária requer muito mais do que a simples mudança do processo legal e do enfoque nas estruturas judiciárias mais arcaicas. Os juízes precisam da colaboração de várias outras instituições estatais para procederem de forma rápida e eficiente. Necessitam ainda da colaboração da polícia, das autoridades políticas e das instituições forenses, para listar apenas algumas. Assim, a mudança judiciária envolve a reforma de outras partes do aparelho do Estado, que deverão estar mais relutantes que os juízes em modificar suas abordagens e valores.

Em terceiro lugar, muitas das críticas atuais apontam para a necessidade de uma abordagem judiciária mais ativa com respeito aos conflitos legais, embebida da defesa dos direitos humanos, na qual os tribunais protejam os direitos das minorias e dos grupos mais desprotegidos. No entanto, não é de todo claro se este papel será apoiado por todos os reformistas, nem se os tribunais de vários países exercerão a legitimidade requerida para realizar uma interpretação crítica das leis aprovadas pela legislatura. Uma preocupação adicional reside no fato de que a interpretação e aplicação da lei, orientadas para o social, pressupõem a participação ativa da sociedade no sentido de explorar novas estratégias legais para cobrar maiores interesses políticos e econômicos. Pessoas passivas, desconhecedoras de seus próprios direitos, ou outras barreiras ao acesso à justiça podem dificultar este processo. 
Então, as estratégias reformistas terão, muito possivelmente, de desenvolver-se lentamente, num esforço de construir as alianças necessárias à mudança. Isto quer dizer que a reforma do sistema de justiça é uma meta de longo prazo, a ser alcançada em sociedades onde os políticos geralmente trabalham em função de políticas de curto prazo.

\subsection{A posição do sistema judiciário no sistema político}

A relação desenvolveu-se entre as cortes de justiça e o sistema político no correr dos anos, de forma a enfraquecer as primeiras. Em vários países da América Latina, os tribunais não eram efetivamente independentes do poder político. Tal dependência pode ser um subproduto da longa tradição histórica de instabilidade política, que sempre ameaçou a estabilidade da carreira dos juízes. Alguns exemplos poderão sustentar esta afirmação. Na Argentina de 1946, um Congresso dominado por Perón declarou o impeachment de todos, com uma só exceção, os membros da Corte Suprema. Em 1957, após a queda de Perón, o recém-empossado governo provisório cassou toda a Corte Suprema, uma atitude que repetiu-se em $1966 .^{70}$ Em 1973, com o retorno ao poder do governo civil, toda a Suprema Corte resignou-se. Houve formas similares de intervenção durante o governo militar que assumiu em 1976. No Peru, houve três intervenções políticas do governo sobre o Judiciário desde 1968. A última aconteceu em abril de 1992, quando o presidente Fujimori suspendeu toda a atividade judiciária por 10 dias; alegando que o Judiciário era corrupto e politicamente infiltrado, ele despediu membros da Corte Suprema, do Conselho Nacional da Magistratura, da Promotoria Pública, das Cortes de Apelação, juízes e outros funcionários graduados. ${ }^{71}$ Em abril de 1993, um Congresso recémeleito determinou cinco pessoas para escolher os candidatos que iriam ocupar todas as posições vagas. ${ }^{72}$

Os governos que favoreceram as recentes reformas políticas e econômicas também intervieram nos tribunais, para ter certeza de que suas políticas seriam implementadas. O presidente Fujimori é um exemplo. Em 1990, o presidente Menem, da Argentina, assegurou o apoio majoritário na Corte Suprema por meio da inclusão de quatro membros, para assim frear os questionamentos sobre as reformas de mercado apresentadas ao Congresso pela sua administração. Desta forma, a conveniência política continua ameaçando a autonomia constitucional dos tribunais, mesmo nos governos democraticamente eleitos. 
O Chile tem sido tradicionalmente um modelo alternativo de relações entre políticos e o sistema judiciário. Em 1925, a profissionalização judiciária foi estabelecida, por meio de um acordo entre os partidos políticos, estabelecendo que o Poder Judiciário não deveria ser politizado. Este acordo influenciou o Judiciário chileno de duas formas: "Ele permite o desenvolvimento de sua autonomia interna, favorecendo o peso das cortes superiores e seus princípios hierárquicos em seu próprio interior; mas também implica uma relativa marginalização dos juízes com relação ao curso da vida social". ${ }^{73}$ No Chile, a estabilidade política entre 1932 e 1973 ajudou a cristalizar uma ideologia judicial tradicional e conservadora, onde os juízes consideram-se meros aplicadores da lei, tendo sido julgados relativamente irrelevantes pela opinião pública, até a explosão da crise política. ${ }^{74}$

Como consequiência, tanto da dependência política ou de um plano de carreira excessivamente burocrático, os sistemas judiciários da América Latina têm relutado em construir uma jurisprudência constitucional que reforce sua influência.

Esta situação resultou em sistemas judiciários que, com exceção da Costa Rica, têm tradicionalmente tido funcionários e verbas insuficientes. Na Colômbia, o orçamento do Judiciário era de 4 a $4,5 \%$ do orçamento nacional anual entre 1982 e 1984. Desde então, ele diminuiu até tornar-se $1,5 \%$ do orçamento total em $1992 " .{ }^{75}$ No Chile, o orçamento para o sistema judiciário nunca esteve acima dos $0,2 \%$ do orçamento nacional total, entre 1977 e $1989 .{ }^{76}$

No Peru, o sistema judiciário recebeu, entre 1965 e 1990, em média $0,48 \%$ do orçamento nacional. ${ }^{77}$

A reforma do Judiciário deveria enfocar seu papel fraco dentro do sistema político, que é causado por diversos fatores. A sua dependência de partidos políticos e do governo, em sociedades onde um governo realmente democrático é mais uma meta que uma realidade, é um deles. As deficiências organizacionais e financeiras também afetaram o status da instituição, que se tornou incapaz de responder às atuais demandas por justiça. Outra causa é a organização burocrática e hierárquica do sistema judiciário na América latina, no qual juízes não dispõem da necessária autonomia com relação aos seus superiores. Este modelo encoraja a conformidade do juiz com a jurisprudência dos tribunais superiores, e desencoraja a originalidade e o auto-aperfeiçoamento, contribuindo para a consolidação de um sistema judiciário composto, por burocratas temerosos do poder do Tribunal Superior, do governo ou das forças armadas sobre suas promoções. ${ }^{78}$ 
Conseqüentemente, alguns autores afirmaram que uma agenda para a modificação do papel atual do sistema judiciário na América Latina requer que ao menos os seguintes pontos sejam tratados: primeiro, que a independência formal do Judiciário seja assegurada por uma autonomia orçamentária e por processos judiciais mais transparentes. Ademais, os postos da carreira judiciária seriam preenchidos por concurso público, onde todos os candidatos deveriam ser avaliados por seus méritos. ${ }^{79}$

Em segundo, o governo e a administração interna dos tribunais deveriam ser validados por um Conselho composto pela maioria dos juízes, mas também tendo uma parte minoritária formada por professores de Direito escolhidos pelo Congresso, de forma que o Conselho não pudesse ser monopolizado pela Suprema Corte ou influenciado pelo governo. Isto evitaria tanto um extremo isolamento da política, como interferência política na carreira dos juízes.

Em terceiro lugar, a capacitação para juízes e oficiais de justiça iria acentuar o valor de seu capital humano, pela crescente qualificação profissional. Em quarto lugar, é necessário um aumento no orçamento e, por último, deve-se garantir a todos o acesso à justiça.

Esta agenda de reforma encontrará, provavelmente, a oposição de muitos políticos e outros detentores de poder — os militares, em muitos casos - que desfrutaram da lealdade daqueles juízes que apoiaram seus processos judiciais. A Suprema Corte de Justiça que não aceitará de boa vontade a alocação de seus poderes administrativos e disciplinares sobre o sistema das cortes para uma organização distinta. Além disto, muitos juízes acharão que um sistema de contratação baseado exclusivamente no mérito poderá prejudicar a estabilidade de suas carreiras judiciárias. Por último, tal agenda requer algumas mudanças nas prioridades orçamentárias, que poderão encontrar oposição de alguns funcionários do governo.

\subsection{A reforma do sistema judiciário como um todo}

O sistema Judiciário completo envolve muito mais do que o sistema de tribunais, e os códigos de processo civil e penal que ditam os procedimentos legais que devem ser seguidos no curso dos processos. O funcionamento das cortes de justiça está intrinsecamente ligado a órgãos auxiliares, como o órgão da promotoria pública, a polícia, os escritórios de advocacia e o sistema penitenciário. Um bom sistema de tribunais deve também assegurar que haja um sistema eficiente de defesa pública, para proteger os direitos daqueles que não podem contratar um advogado. Por último, as leis modernas civis e criminais deverão estar sempre atualizadas para serem aplicadas pelos tribunais. 
Recentemente, um especialista alemão que visitava o Chile calculou que a reforma do sistema de justiça penal naquele país duraria 15 anos. Primeiramente, declarou ele, o Código Penal deveria ser substituído por um novo. Além disso, deveria ser estabelecida uma nova legislação sobre a responsabilidade penal de menores, um órgão de promotoria pública, e a polícia deveria receber novo treinamento, para colaborar mais de perto com o Judiciário e respeitar os direitos civis. ${ }^{80}$

Uma análise recente, realizada no Chile sobre 100 casos de assalto e furto, mostrou que o tempo que a polícia passava cumprindo as ordens dadas pelos juízes criminais tinha uma importante influência nos atrasos dos processos. Em 77,4\% dos casos, a polícia levava entre um e quatro meses para verificar e informar ao tribunal se determinado crime havia sido realmente cometido ${ }^{81}$ Com relação às ordens de prisão a pessoas livres sob fiança que haviam recebido sentença, os resultados eram igualmente perturbadores: em 54,2\% dos casos, a polícia não conseguiu localizá-las. ${ }^{82}$

Em quase todos os países da América Latina, a polícia está subordinada ao Ministério do Interior ou ao Ministério da Defesa. Assim, os juízes têm pouca influência sobre o acompanhamento dos procedimentos adotados pela polícia, ou sobre a alocação de tempo para casos diferentes, ou mesmo para controlar a corrupção dentro daquela instituição.

A coordenação dos esforços da polícia sempre foi uma tarefa difícil para a autoridade civil investida àquele poder. Na Colômbia, a Fiscalía General dispõe de sua própria polícia, força policial, e coordena e dirige as outras forças policiais para a investigação de crimes. No entanto, numa entrevista recente, o Fiscal General confessou-me que a Fiscalía não dispunha de capacidade administrativa para implementar esta coordenação.

A tarefa de controlar e dirigir o trabalho da polícia torna-se mais difícil quando existem forças policiais diferentes que dividem tarefas muitas vezes sobrepostas, sendo dirigidas por autoridades diferentes e tendendo a competir pelos mesmos recursos. Na Colômbia, por exemplo, os crimes podem ser investigados pela Polícia Nacional, que tem um perfil militar e é supervisionada pelo Ministério da Defesa; pelo Corpo Técnico de Investigação, que faz parte da Fiscalía Geral, ou pelo DAS, que é ligado à Presidência da República. No caso chileno, os Carabineros e a Polícia de Investigaciones são subordinados ao ministro da Defesa, mas enquanto o Corpo de Investigação está submetido à jurisdição civil, pela comissão de delitos realizados durante o desempenho de suas funções, enquanto que os Carabineros estão submetidos aos tribunais militares pelos delitos cometidos durante suas funções. 
Em muitos países da América Latina, o nível do crime é tão

alto que o Exército participa diretamente da repressão ao crime comum, o que torna o controle sobre as investigações criminais ainda mais difícil. ${ }^{83}$ Isto também comprova a falta de coerência de uma estratégia civil eficiente e coerente para erradicar o crime das ruas.

Qualquer reforma no sistema de justiça penal atual deverá resultar em melhorias importantes da situação existente, como mostrou-nos a experiência colombiana. ${ }^{84}$ No entanto, sem a colaboração irrestrita da polícia ao Judiciário, e sem respeito aos direitos do acusado, um sistema de justiça realmente contestatório nunca será alcançado. Assim, a reforma judiciária envolve necessariamente a reforma de outras instituições públicas, sem a qual o sucesso da primeira será somente parcial.

\subsection{O Judiciário na democracia}

Numa democracia, os juízes exercem um papel fundamental na manutenção da Constituição e de seus princípios, e por isto devem ser independentes de qualquer interferência governamental. Entretanto, eles têm suas convicções próprias, que influenciam diretamente suas decisões. Os juízes devem sempre julgar de acordo com determinados valores. Na maioria das sociedades democráticas, um papel criticamente ativista dos tribunais é amplamente aceito por políticos e teóricos. Isto não ocorre na América Latina, onde a tendência a um papel mais explicitamente político por parte do Judiciário é geralmente combatido, mesmo por aqueles a favor da reforma judiciária.

O tema do papel social e político dos juízes na democracia irá influenciar ativamente o processo de avanço das reformas judiciárias. Alguns grupos simplesmente pregarão uma racionalização burocrática e uma melhor capacitação para os juízes, esperando confinar as reformas a áreas de direito corporativo e de litígio civil, ao passo que outros defenderão um sistema judiciário voltado à proteção e ao desenvolvimento da cidadania democrática. $\mathrm{O}$ debate sobre estas concepções será um fator importante para a decisão sobre o passo, a velocidade e a extensão das reformas que serão implementadas.

\subsection{O impacto do acesso à justiça na mudança institucional}

O funcionamento atual dos sistemas legais latino-americanos depende das reformas legais e institucionais, mas também do acesso à justiça. Somente se o sistema for acessível a todos aqueles que 
desejem justiça, e somente se eles fizerem uso do sistema legal para tornar real o direito dos indivíduos comuns, é que a máquina da justiça deverá ganhar legitimidade. Até o momento, muitas tendem a evitar conflitos legais, pois as barreiras à justiça efetiva são imensas. Assim, o Judiciário ainda não está sendo utilizado amplamente como um canal eficaz de solucionar disputas sociais e legais.

As barreiras à justiça que devem ser superadas em nossos sistemas legais são os custos envolvidos no litígio e na relativa capacidade das partes envolvidas. ${ }^{85}$ Os principais custos envolvidos são as despesas com advogado e o tempo necessário para obter-se uma decisão judicial.

$\mathrm{Na}$ América Latina, os pobres têm acesso a uma assistência legal muito deficiente, onde os casos criminais quase não têm espaço. ${ }^{86}$ Nenhuma reforma ao sistema de justiça poderá ser completa sem um aperfeiçoamento real dos programas de assistência legal apoiados pelo Estado. Durante as décadas de 70 e 80, a inovação da assistência legal prestada por ONGs emergiu em toda a América Latina, visando à promoção de mudanças legais, econômicas e políticas na região. ${ }^{87}$ Todavia, os recentes cortes em financiamentos internacionais para estes serviços enfraqueceram sua presença institucional, especialmente no Cone Sul.

Os custos, em termos do tempo envolvido nos litígios, são especialmente altos em países onde tais sistemas judiciários estão sobrecarregados de casos em que eles são incapazes de resolver dentro de prazos razoáveis.

Um outro grande obstáculo à justiça é o fato de que certas partes desfrutam de vantagens não acessíveis àquelas mais fracas. Tais vantagens consistem, em primeiro lugar, do conhecimento de seus direitos. Esta barreira é especialmente séria para os pobres, mas aplica-se à maioria da população em alguns casos. Muita gente poderá desconhecer que um determinado direito exista, e deverá desconhecer o funcionamento atual do sistema legal. Além disto, algumas partes possuem recursos financeiros consideráveis que poderão ser utilizados no litígio, dispondo assim de uma vantagem substancial na defesa de suas petições. ${ }^{88}$

Um uso mais intenso dos direitos alegados mostra-se essencial para a promoção do funcionamento de um sistema legal democrático. Caso as barreiras ao acesso à justiça continuem intransponíveis, esta meta será atrasada, desconsiderando-se outras reformas que deverão ser implementadas. Isto sugere que as reformas institucionais do Poder Judiciário deverão ser complementadas por uma mobilização poderosa dos direitos daqueles que buscam justiça e do sentimento de responsabilidade pública das autoridades eleitas. 


\section{Conclusões}

Pela primeira vez em décadas, a América Latina está assistindo à emergência de um movimento relativamente forte visando à reforma judiciária. As forças que se combinaram para advogar por estas mudanças são diversas, incluindo defensores dos direitos humanos e dos princípios do Direito, que criticavam os governos autoritários anteriores, os governos estrangeiros e as instituições internacionais interessadas na manutenção da ordem interna e na estabilidade econômica, como também os empresários locais preocupados com as inadequações dos sistemas legais nacionais, face à integração global.

Até agora, os membros dos movimentos concordaram com várias das reformas, embora ainda haja diferenças entre aqueles que as defendem. ${ }^{89}$ Os tópicos cobertos por estes esforços são:

a) o aperfeiçoamento da capacidade administrativa do sistema judiciário para reduzir a ineficiência, os atrasos e a corrupção;

b) a promoção de centros de capacitação judiciária para convencer os juízes da necessidade da reforma, e para treiná-los nas práticas administrativas e legais necessárias para seu trabalho;

c) a introdução de processos orais e contestatórios no sistema penal, para aumentar o percentual de condenações, aumentando o exercício dos direitos humanos pelos acusados; e

d) a implementação e a promoção de processos alternativos de solução de disputas, visando desviar do Judiciário aqueles conflitos que poderiam ser melhor resolvidos por métodos diferentes do julgamento formal.

A implementação destas mudanças pode realmente significar uma melhoria na qualidade dos sistemas democráticos recentemente instalados, já que elas podem criar um poder Judiciário mais ativo e aberto. No entanto, as dificuldades desta tarefa são inevitáveis. Primeiramente, porque a verdadeira reforma do Judiciário pressupõe a mudança da posição do Judiciário dentro dos sistemas políticos latino-americanos. Estes sistemas judiciários ainda dependem do governo ou dos partidos, ou são compostos por juízes muito dependentes de seus superiores para aplicarem princípios muito criativos na interpretação da lei. Em segundo lugar, a reforma do sistema judiciário envolve a reforma de outras instituições públicas, como a polícia, sem as quais as modificações legais seriam meramente superficiais, de fachada. Em terceiro lugar, porque o desenvolvimento de um sistema judiciário forte e autônomo exige um acordo social a respeito do papel do próprio Judiciário numa democracia. Finalmente, quase tudo o que ocorre no sistema 
judiciário dependerá da existência de grupos não-governamentais ativos, dispostos a utilizar a lei para defender os direitos civis e fazer cumprir as decisões legais.

As razões para a emergência de um novo movimento são bem claras. Elas são a combinação de razões nacionais e internacionais, entre as quais está a longa insatisfação com o Judiciário; o impacto da democratização política, que tem resultado em iniciativas de mudanças, enviadas aos congressos de vários países; e os interesses internacionais sustentadas nestas reformas, que resultaram em um aumento nos recursos necessários para seu estudo e implementação.

Assim, tudo parece sugerir que as mudanças institucionais virão de forma lenta e gradual, e que as reformas mais extensas deverão surgir naqueles países que contam com um bom nível de efetiva governança, que puseram em marcha modificações no mercado, e que fazem uso efetivo do sistema legal para a defesa dos menos favorecidos.

\section{Notas}

1 Artigo publicado, também, em "Fault Lines of Democratic Governance in the Americas", Felipe Agüero and Jeffrey Stark, editors, 1997.

2 Walter F. Murphy. 1993. "Constitutions, Constitutionalism and Democracy". Em Constitutionalism and Democracy: Transitions in the Contemporary World. Douglas Greenbert et. al. eds., (Nova Iorque: Oxford University Press), p.3-7.

3 Mesmo uma visão autoritária da norma da lei exige a diferenciação dos processos da legislação, administração e adjudicação. Na norma da lei democrática, no entanto, cada pessoa deve participar do processo de construção do direito, e o principal papel dos juízes é a proteção dos direitos constitucionais. Ver Roberto Mangabeira Unger. 1976. Law in Modern society: towards a criticism of social theory (Nova Iorque: The Free Press), 54, p.176-178.

4 Lisa Hilbink, 1995. "What is the Role of the Judiciary in a Democracy? The Judicial Reform Debate in Chile and Prospects for Future Research". Documento apresentado em 1995, na reunião da Associação de Estudos Latinoamericanos, p.11-16.

5 Para uma análise comparativa do Judiciário na América Latina, ver Jorge Correa ed. 1994. Situación y Políticas Judiciales en América Latina (Santiago: Escuela de Derecho Universidad Diego Portales). Rogelio Pérez Perdomo, 1987 "La Administración de Justicia en Venezuela: Evaluación y Alternativas", na Revista de Derecho Privado 2-4. Luis Pásara, "Peru: Administracion de ¿Justicia?”, em Javier de Belaúnde ed.. 1984, La Administración de Justicia 
en América Latina, (Lima" Consejo Latinoamericano de Derecho y Desarrollo). Keith Rosenn, 1987, "The Protection of Judicial Independence in Latin America”. Interamerican Law Review 19 (1): 1-35. Joel G. Verner, 1984, "The Independence of the Supreme Court in Latin America: A Review of the Literature", Journal of Latin American Studies. 16: 463-506.

6 Alguns autores interpretaram a recorrência de violações dos direitos humanos como um subproduto de uma cultura política autoritária. Veja, em geral, Howard J. Wiarda, ed., 1982. Politics and Social Change in Latin America: The Distinct Tradicion (Amherst, Mass: University of Massachusetts Press). Brian Loveman, em livro recente, afirmou que as fundações constitucionais para a repressão e intolerância ainda estão presentes na maioria das nações latinoamericanas. Ver Brian Loveman, 1993, The Constitution of Tyranny. Regimes of Exception in Spanish America (Pittsburgh: University of Pittsburgh Press).

7 Teresa P.R. Caldeira e James Holston, 1995. "Citizenship, Justice, Law: Limits and Prospects of Democratizating in Brazil", neste volume, 11.

8 Unger 1976, 228.

9 Ver Hugo Frühling. 1984. Law in Society. Social Transformation and the Crisis of Law in Chile. 1930-1970, S.J.D. Tese submetida à Escola de Direito de Harvard, 291. Eduardo Novoa, 1965. "La Crisis del Sistema Legal Chileno", Revista de Derecho Jurisprudencia y Ciencias Sociales 62:229.

10 Eduardo Novoa, 1965, p.230-231.

11 Eduardo Novoa, 1964, "La Crisis del Sistema Legal Chileno", Mensaje, 13: p.563-564.

12 Ver Edmundo Fuenzalida, 2977, "The Role of Legal Experts in the Process of Development. The Case of Chile", documento preparado para o Institute of Development Studies da Universidade de Sussex.

13 Richard J. Wilson, 1989, "The New Legal Education in North and South America", Stanford Journal of International Law 25 (2): 393-394.

14 James A. Gardner, 1980, Legal Imperialism. American Lawyers and Foreign Aid in Latin America (Wisconsin: Wisconsin Universy Press), 6-12.

15 Steven Lowenstein, 1970 Lawyers, Legal Education and Development. An Examination of the Process of Reform in Chile, 65-74.

16 Hugo Frühling, 1984, 297-298.

17 Richard Wilson, 1989, 394.

18 Hugo Frühling, "Poder Judicial y Político en Chile", em Javier de Belaúnde, ed., 1984. Luis Pásara, 1984.

19 Carlos José Gutiérrez, 1973, "Los Jueces de Costa Rica”, Revista de Ciencias Jurídicas, Universidade da Costa Rica, 22 (Setembro): 77 - 113. Luis Pásara, 1984.

${ }^{20}$ Uma exceção clara aconteceu no Peru, onde foi criada em 1975 uma Comissão de Reforma Judicial, que organizou seminários de capacitação para juízes, em colaboração com o Conselho Latino-americano de Direito e Desenvolvimento.

${ }^{21}$ Edgardo Buscaglia e María Dakolias, 1995, "Judicial Reform in Latin America. Economic Efficiency vs. Institutional Inertia", documento apresentado à Conferência da LASA de 1995, 12.

22 Para uma boa consideração da situação dos direitos humanos no Chile, ver Organização dos Estados Americanos, Comissão Interamericana de Direitos Humanos, 1985, Informe sobre la Situación de los Derechos Humanos en Chile (Washington, D.C., OEA).

23 Um destes casos foi o do juiz Carlos Cerda, que conduziu uma investigação sobre o desaparecimento de 12 líderes comunistas em 1976. Ele condenou 38 membros das Forças Armadas e dos Carabineros. Recentemente, o caso foi 
encerrado pela Corte Suprema, que aplicou uma lei de anistia aprovada pela Junta Militar em 1978.

24 Hugo Frühling, 1984, "Poder Judicial y Político", Lisa Hilbink, 1995.

25 Jorge Correa Sutil e Luis Barros Lazaeta, (eds.) 1993, Justicia y Marginalidad. Percepción de los Pobres (Santiago: CPU - Dirección de Estudios Sociológicos de la U. Católica), 136.

26 Keneth Anderson, "Maximizing Deniability: The Justice System and Human Rights in Guatemala", 1989, (Washington, D.C.: International Human Rights Law Group), 9-10.

27 Keneth Anderson, 1989, 10.

28 Teresa P.R. Caldeira e James Holston, 1995, 20.

${ }^{29}$ Margaret Popkin, 1994, Justice Delayed. The Slow Pace of Judicial Reform in El Salvador (Washington D.C.: Hemisphere Initiatives and Washington Office on Latin America). Gino Costa, 1994, "La Reforma Policial en el Salvador", mimeo.

30 Instituto SER de Investigación, 1983, Justicia Penal, Juicio y Reforma, (Bogotá: FESCOL)

${ }^{31}$ Rafael Blanco e Hugo Frühling, 1995. "Proposiciones de Políticas Públicas en Materia de Seguridad Ciudadana", em Rafael Blanco, Hugo Frühling e Eugenio Guzmán, Seguridad Ciudadana. Políticas Públicas. Santiago, Universidad Nacional Andrés Bello, CED, ILD.

32 Keneth Anderson, 1989, 12-28.

33 Julio B. Maier, "Democracia y Administración de Justicia Penal en Iberoamérica. Los Proyectos para la Reforma del Sistema Penal" em Julio Maier et. al., 1993, Reformas Procesales en América Latina La Oralidad de los Procesos (Santiago: CPU), 25-66. Alberto M. Binder, "Crisis y Transformación de la Justicia Penal en Iberoamérica', em Julio Maier et.al., 1993, 67 - 95.

34 Alberto Binder, "La Reforma Procesal Penal en América Latina", em Corporación de Promoción Universitaria y Fundación Paz Ciudadana, "Proyecto para la Reforma del Procedimiento Penal Chileno", 1994, (Santiago: Corporación de Promoción Universitaria), 36-37. Um estudo chileno recente, onde 100 arquivos jurídicos foram examinados, mostra que, ao final, foi descoberta a culpa de quase todos os acusados de crime, e que seus recursos foram recusados. Ver Luis Barros, Hugo Frühling, Gonzalo García, Augusto Quintana e Domingo Sanchez, "El Proceso Penal Chileno y su Protección de los Derechos del Imputado", em Corporación Nacional de Reparación y Reconciliación, 1994, Proceso Penal y Derechos Fundamentales, Santiago.

35 Fernando Calderón e Mario Dos Santos, 1991, Hacia un Nuevo Orden Estatal en América Latina. Veinte Tesis Sociopolíticas y un Corolario (Comentários de Alejandro Foxley, Fernando H. Cardoso. E. Faletto, A. Touraine), Fondo de Cultura Económico.

36 Para uma análise da operação do sistema legal sob um estado regulador latinoamericano, ver Hugo Frühling, Law in Society, 1984. Para uma análise comparativa com a situação atual, ver Carlos Peña Gonzalez, 1994, "América Latina: Una Justicia Emergente?" em Boletín Comisión Andina de Juristas, 41 (Junho): 9-17. Rogelio Pérez Perdomo, 1993, "La Justicia en Tiempos de Globalización: Demandas y Perspectivas de Cambio", em Banco Interamericano de Desenvolvimento, Justicia y Desarrollo en América Latina y el Caribe (Washington D.C.: Banco Interamericano de Desenvolvimento), 137-151.

37 Rogelio Pérez Perdomo, 1993, 140-141. 
38 Rogelio Pérez Perdomo, 1993, 142-151.

39 Carlos Peña Gonzalez, 1994, 14.

40 J.J. Toharía, 1987 Pleitos Tengas... Introducción a la Cultura Legal Española. M. Galanter e J. Rogers, "A Transformation of American Business Disputing. Some Preliminary Observations", documento de trabalho, 1991, citado por Rogelio Pérez Perdomo, 1993, 146.

41 Edgardo Buscaglia e Maria Dakolias, 1995, 6-7.

42 Ver World Competitiveness Report, 1994 (Washington D.C.), 34-36.

43 Carlos Manuel Garrido, "Informe Sobre Argentina", em Jorge Correa Sutil (ed.), 1994, 77.

44 Edgardo Buscaglia e María Dakolias, 15, 13.

45 Estamos acompanhando de perto Thomas Carothers, 1994, "The Resurgence of United States Political Development Assistance to Latin America”, documento não publicado.

46 Thomas Carothers, 1994, 17.

47 Carothers, 1994, 18.

48 Carothers, 1994, 25.

${ }^{49}$ Em 1990, um programa do U.S. AID de ajuda jurídica à Guatemala, administrado pelo Centro de Justiça Penal da Faculdade de Direito de Harvard, foi encerrado, com a justificativa de que o governo não havia feito esforços para investigar assassinatos políticos. El Habeas Corpus en Centro América, Serie Jurídica n.2 (San José: CODEHUCA), 49-51.

50Thomas Carothers, 1994, 28, 29.

51 "Elusive Justice, the U.S. Administration of Justice Programme in Latin America". 1990, Washington, D.C.: WOLA, 12.

52 Thomas Carothers, op.cit., 41.

53 William Davis, 1993, “Administraciíon del Proceso de Introducción de Reformas en los Tribunales", em Julio Maier et.al. Reformas Procesales en América Latina. La Oralidad en los Procesos (Santiago: CPU), 203-212.

54 Jaime Giraldo Angel, "Informe Sobre Colombia”, em Jorge Correa Sutil (ed.), 1994, $141-151$.

55 Jorge Correa Sutil, 1992, "Formación y Perfeccionamiento de Jueces", em Carlos Peña et.al., El Poder Judicial en la Encrucijada (Santiago"Escola de Direito da Universidade Diego Portales), 115-116. Com financiamento do AID, foi realizada uma pesquisa de experiências comparativas de treinamento jurídico no Chile. Ver María Josefina Haeussler, 1993 Experiencias Comparativas de Formación Judicial (Santiago: CPU).

56 Rogelio Pérez Perdomo, 1994 "Informe Sobre Venezuela", em Jorge Correa Sutil (ed.), 592-594.

57 Jaime Giraldo Angel, 1994, "Informe Sobre Colombia” em Jorge Correa Sutil (ed.), 167 - 170.

58 Enrique V. Iglesias, "Derecho, Justicia y Desarrollo en América Latina en la Década de los Noventa", em Banco Interamericano de Desenvolvimento, 1993, 9.

${ }^{59}$ Enrique Iglesias, 1993, 10-11.

${ }^{60}$ Néstor Humberto Martínez Neira, "El BID y la Administración de Justicia", em Banco Interamericano de Desenvolvimento, 1993, 321-330.

${ }^{61}$ Ver Carlos Peña G., "Poder Judicial y Sistema Político. Las Políticas de Modernización”, em Carlos Peña et.al., El Poder Judicial en la Encrucijada. Estudios Acerca de la Política Judicial en Chile (Santiago: Escuela de Derecho Universidad Diego Portales, 1992), 48. Minhas entrevistas com funcionários do governo da época convenceram-me de que o governo de Aylwin considerou 
o pacote legislativo de reforma jurídica uma resposta adequada ao relatório da Comissão Rettig que documentava as violações dos direitos humanos ocorridas no Chile durante o governo militar.

62 Mario Verdugo, "Alternativas de la Reforma del Poder Judicial”, em Carlos Peña et.al., 1992, 57-77.

63 John Dugas, 1993, "La Constitución Política de 1991, Un Pacto Político Viable?, em John Dugas (compilador), La Constitución Política de 1991: Un Pacto Político Viable? (Bogotá: Departamento de Ciência Política da Universidade de Los Andes).

64 Jaime Giraldo Angel, 1994.

65 René Hernández Valiente, "La Justicia en Centro América en la Década de los Noventa", em Banco Interamericano de Desenvolvimento, Justicia y Desarrollo en América Latina y el Caribe, 1993, 65-86.

66 Kurt Weyland, "The Rise and Fall of President Collor and its Impact on Brazilian Democracy", em Journal of Interamerican Studies and World Affairs 35 (1): 1993. Carlos M. Ayala Carao, "El Enjuiciamiento del Presidente de Venezuela: Suspensión y Suplencia”, em Boletín Comisión Andina de Juristas 37 (junho): 49-52.

67 Rogelio Pérez Perdomo, 1993, 147. Pilar Domingo, num documento recente apresentado na Conferência da LASA em 1995, argumentou que alguns setores econômicos, mais sintonizados com a liberação econômica, estão dispostos a apoiar a crescente independência do judiciário. Como evidência, ela cita o discurso da elite econômica de Chihuahua. Ver Pilar Domingo, 1995, "The Judiciary and the Rule of Law in Latin America", documento não publicado, disponível em meus arquivos. Y. Mizrahi, 1994 "Rebels Without a Cause? The Politics of Enterpreneurs in Chihuahua", no Journal of Latin American Studies 16: 137-158.

68 De acordo com este ponto de vista, a transição consolidou a democracia protegida, onde os regimes de exceção são elementos básicos das constituições, as forças armadas mantêm a segurança interna e um papel político, e dispõem de uma autonomia parcial. Ver Brian Loveman, "Protected Democracies and Military Guardianship: Political Transitions in Latin america, 1978 - 1993", 1994, em Journal of Interamerican Studies, 36 (2): 105-188.

${ }^{69}$ Hugo Frühling, "Human Rights in Constitutional Order and in Political Practice in Latin America", 1993, em Douglas Greenberg et.al.), Constitutionalism and Democracy. Transitions in the Contemporary World, Nova Iorque: Oxford University Press, 99.

70 Keith S. Rosenn, "Judicial Review in Latin America”, em Ohio State Law Journal 35 (1974): 509-510.

${ }^{71}$ Lorenzo Zolezzi Ibárcena, "Informe Sobre Perú”, em Jorge Correa Sutil (ed.), 1994, 495-498.

72 Ver Fernando de Trazegnies Granda, "Poder Judicial. El Jurado de Honor de a Magistratura: Balance de Cierre" em ideele 71-72 (dezembro 1994): 99-103.

73 Hugo Frühling, 1984, 118.

74 Carlos Peña González, 1994, 11.

75 Jaime Giraldo Angel, 1994, 140.

76 Carlos Peña González, "Informe Sobre Chile”, em Jorge Correa Sutil (ed.), 1994, 336.

77 Lorenzo Zolezzi Ibárcena, 1994, 494.

${ }^{78}$ Eugenio Raúl Zaffaroni, "Dimensión Política de un Poder Judicial Democrático”, em Boletín Comisión Andina de Juristas 37 (junho 1993): 9-40. 
79 Eugenio Raúl Zaffaron, 1993, 37, 38.

${ }^{80}$ El Mercurio, 29 de março de 1995, C15.

81 Luis Barros, Hugo Frühling, Gonzalo García, Augusto Quintana, Domingo Sanchez, 1994, 153.

82 Luis Barros, Hugo Frühling, Gonzalo García, Augusto Quintana, Domingo Sanchez, 1994, 153.

83 "Presidente de Guatemala Ordenó al Ejército Salir a las Calles", em La Epoca, 28 de março de $1995,3$.

${ }^{84}$ Uma avaliação recente do sistema de justiça penal na Colômbia mostra que dois anos após a reforma constitucional de 1991, o número de casos criminais não solucionados continua bastante similar. No entanto, o percentual de casos onde há um acusado do crime é maior. Ver "La Justicia Dos Años Después de la Reforma Constitucional”, em Coyuntura Social 11 (novembro de 1994): 36-39.

85 Mauro Cappelletti e Bryant Garth, "Access to Justice: the Newest Wave in the Worldwide Movement to Make Rights Effective", Buffalo Law Review 27 (1978) 181-196.

86 Luis Barros, Hugo Frühling, Gonzalo García, Augusto Quintana e Domingo Sanchez, 1994, 163.

87 Joseph Thome, "New Models for Legal Services in Latin America", em Human Rights Quarterly, 6 (novembro de 1983) 521-538. Fernando Rojas, "A Comparison of Change-Oriented Legal Services in Latin America with Legal Services in North America and Europe", documento de trabalho, Instituto de Estudos Legais da Faculdade de Direito da Universidade de Wisconsin, 1986).

88 Mauro Cappelletti e Bryant Garth, 1978, 186-193.

89 Ver, por exemplo, as críticas contra algumas reformas do processo penal já implementadas, por Juan Enrique Vargas Viancos, "Reforma Procesal Penal en América Latina" La Adecuacíon de las Legislaciones al Programa de los Derechos Humanos", em Corporación Nacional de Reparación y Reconciliación, 1994, 275-316. Ver também nossa referência prévia a duas visões relativas ao papel dos tribunais na proteção e promoção da cidadania democrática.

\section{Referências bibliográficas}

Anderson, Keneth. 1989. "Maximizing Deniability: The Justice System and Human Rights in Guatemala". Washington, D.C., International Human Rights Law Group.

Ayala Carao, Carlos M. 1993. "El Enjuiciamiento del Presidente de Venezuela: Suspensión y Suplencia. Boletín Comisión Andina de Juristas, 37:49-52.

Binder M., Alberto. 1993. "Crisis y Transformación de la Justicia Penal en Iberoamérica". Em Reformas Procesales en América Latina. La Oralidade en los Procesos. Santiago: CPU.

Binder M., Alberto. "La Reforma Procesal Penal en América Latina". Em "Proyecto para la Reforma del Procedimiento Penal Chileno", Corporación de Promoción Universitaria e Fundación Paz Ciudadana, manuscrito não publicado. 
Blanco, Rafael e Frühling, Hugo. 1995. "Proposiciones de Políticas Públicas en Materia de Seguridade Ciudadana". Em Seguridade Ciudadana. Políticas Públicas, Blanco Rafael, Hugo Frühling e Eugenio Gszmán. Santiago: Universidade Nacional Andrés Bello, CED, ILD.

Buscaglia, Edgardo e María Dakolias. 1995. "Judicial Reform in Latin America. Economic Efficiency vs. Institutional Inertia”. Manuscrito não publicado.

Caldeira, P.R., Teresa e James Holston. 1995. "Citizenship, Justice, Law: Limits and Prospects of Democratization in Brazil", neste volume.

Calderón, Fernando e Mario Dos Santos. 1991. Hacia un Nuevo Orden Estatal en América Latina. Veinte Tésis Sociopolíticas y un Corolario. México: Fondo de Cultura Económico.

Cappelletti, Mauro e Bryant, Garth. 1978. "Access to Justice: The Newest Wave in the Worldwide Movement to Make Rights Effective". Buffalo Law Review 28: 181-196.

Carothers, Thomas. 1994. "The Resurgence of United States Political Development Assistance to Latin America". A ser lançado.

Correa Sutil, Jorge. "Formación y Perfeccionamiento de Jueces". 1992. Em El Poder Judicial en la Encrucijada. Santiago: Escola de Direito da Universidade Diego Portales.

Correa Sutil, Jorge e Luis Barros Lazaeta, eds. 1993. Justicia y Marginalidad. Percepción de los Pobres. Santiago: CPU - Direção de Estudos Sociológicos da Universidade Católica.

Correa, Jorge, ed. Situación y Políticas Judiciales en América Latina. 1994. Santiago: Escola de Direito da Universidade Diego Portales.

Costa, Gino. 1994. "La Reforma Policial en El Salvador". Manuscrito não publicado.

Davis, William. 1993. "Administración del Processo de Introducción de Reformas en los Tribunales". Em Reformas Procesales en América Latina. La Oralidade en los Procesos, Santiago: CPU.

De Trazegnies, Fernando. 1994. "El Jurado de Honor de la Magistratura: Balance de Cierre". ideele 71-72: 99-103.

Domingo, Pilar. 1995. "The Judiciary and the Rule of Law in Latin America". Manuscrito não publicado.

Drugas, John. 1993. "La Constitución Política de 1991, ¿Un Pacto Político Viable?" Em La Constitución Política de 1991. ¿Un Pacto Político Viable?. John Dugas, ed. Bogotá: Departamento de Ciência Política da Universidade dos Andes.

"El Habeas Corpus en Centro América". 1992. San José: CODEHUCA.

"Elusive Justice. The U.S. Administration of Justice Program in Latin America". 1990. Washington, D.C.: WOLA.

FrÜHLING, Hugo. 1984. Law in Society. Social Transformation and the Crisis of Law in Chile. 1930-1970. S.J. D. Tese submetida à Escola de Direito de Harvard.

Frühling, Hugo. 1984. "Poder Judicial y Político en Chile". Em La Administración de Justicia en América Latina, ed. Javier de Belaúnde. Lima: Consejo Latinoamericano de Derecho y Desarrollo.

FRÜHLING, Hugo. 1983. "Human Rights in Constitutional Order and in Political Practice in Latin America". Em Constitutionalism an Democracy. Transitions in the Contemporary World, eds. Douglas Greenberg, Stanley N. Katz, Melanie Beth Oliviero e Steven C. Wheatley. Nova Iorque: Oxford University Press.

Fuenzalida, Edmundo. 1977. "The Role of Legal Experts in the Process of Development. The Case of Chile". Manuscrito não publicado.

GARDNER A., James. 1980. Legal Imperialism. American Lawyers and Foreign Aid in Latin America. Wisconsin: Wisconsin University Press. 
Garrido, Carlos Manuel. 1994. "Informe sobre Colombia”. Em Situación y Políticas Judiciales en América Latina, ed. Jorge Correa. Santiago: Escola de Direito da Universidade Diego Portales.

Gutiérrez, Carlos José. 1973 "Los Jueces de Costa Rica". Revista de Ciências Jurídicas 22: 77-113.

Haeussler, Josefina. 1993. Experiencias Comparativas de Formación Judicial. Santiago: CPU.

Hernández Valiente, René. 1993. "La Justicia en Centroamérica en la Década de los Noventa". Em Justicia y Desarrollo en América Latina y el Caribe. Washington, D.C.: Banco Interamericano de Desenvolvimento.

Hilbink, Lisa. 1995. "What is the role of the Judiciary in a Democracy? The Judicial Reform Debate in Chile and Proposals for Future Research". Manuscrito não publicado.

Iglesias V., Enrique. 1993. "Derecho, Justicia y Desarrollo en América Latina en la Década de los Noventa". Em Justicia y Desarrollo en América Latina y el Caribe. Washington, D.C.: Banco Interamericano de Desenvolvimento.

Loveman, Brian. 1994. "Protected Democracies and Military Guardianship: Political Transitions in Latin America. 1878-1993". Journal of Interamerican Studies 36: 105-188.

LowensteIn, Steven. 1970. Legal Education and Development: An Examination of the Process of Reform in Chile. Nova Iorque: International Legal Center.

Luis Barros, Hugo Frühling, Gonzalo García, Augusto Quintana e Domingo Sanchez. 1994. "El proceso Penal Chileno y su Protección de los Derechos del Imputado". Em Proceso Penal y Derechos Fundamentales. Santiago: Corporación Nacional de Reparación y Reconcilición.

Martínez Neira, Néstor Humberto. 1993. "El Bid y la Administración de Justicia". Em Justicia y Desarrollo en América Latina y el Caribe. Washington, D.C.: Banco Interamericano de Desenvolvimento.

Mizrahi, Y. 1994. "Rebels Without a Cause? The Politics of Entrepreneurs in Chihuahua". Journal of Latin American Studies 26: 137-158.

Murphy F., Walter. 1993. "Constitutions, Constitutionalism, and Democracy". Em Constitutionalism \& Democracy. Transitions in the Contemporary World. eds Greenberg, Douglas, Stanley N. Katz, Melanie Beth Olivieroe Steven C. Wheatley. Nova Iorque: Oxford University Press.

NovoA, Eduardo. 1964. "La Crisis del Sistema Legal Chileno". Mensage 13: 563564.

NovoA, Eduardo. 1965. "La Crisis del Sistema Legal Chileno". Revista de Derecho, Jurisprudencia y Ciencias Sociales. $62: 229$.

PÁsARA, Luis. 1984. "Perú: Administración de ¿Justicia?”. Em La Administración de Justicia en América Latina. ed. Javier de Belaúnde. Lima: Consejo Latinoamericano de Derecho y Desarrollo.

PeÑa, Carlos. 1992. "Poder Judicial y Sistema Político. Las Políticas de Modernización". Em El Poder Judicial en la Encrucijada. Estudios Acerca de la Política Judicial en Chile. Santiago: Escola de Direito da Universidade Diego Portales.

PeÑA, Carlos. 1994. "América Latina: ¿Una Justicia Emergente?. Em Boletín Comisión Andina de Juristas 41: 9-17.

PeÑA, Carlos. 1994. "Informe sobre Chile". Em Situación y Políticas Judiciales en América Latina. Ed. Jorge Correa. Santiago: Escola de Direito da Universidade Diego Portales.

Pérez Perdomo, Rogelio. 1987. "La Administración de Justicia en Venezuela: Evaluación y Alternativas". Revista de Derecho Privado 2-4.

Pérez Perdomo, Rogelio. 1993. "La Justicia en Tiempos de Globalización: Demandas y Perspectivas de Cambio". Em Justicia y Desarrollo en América Latina y el Caribe. Washington, D.C.: Banco Interamericano de Desenvolvimento. 
Pérez Perdomo, Rogelio. 1994. "Informe sobre Venezuela". Em Situación y Políticas Judiciales en América Latina. ed. Jorge Correa. Santiago: Escola de Direito da Universidade Diego Portales.

PoPKIN, Margaret. 1994. Justice Delayed. The Slow Pace of Judicial Reform in El Salvador. Hemisphere Initiatives e Washington Office on Latin America.

Rosenn S., Keith. 1974. "Judicial Review in Latin America". Em Ohio State Law Journal 35: 509.

Rosenn S., Keith. 1987. "The Protection of Judicial Independence in Latin America”. Interamerican Law Review 19 (1): 1-35

Tноме, Joseph. 1983. "New Models for Legal Services in Latin America". Em Human Rights Quarterly 6: 521-538.

Rivera Cira, Tirza. 1994. "Informe sobre Costa Rica”. Em Situación y Políticas Judiciales en América Latina. ed. Jorge Correa. Santiago: Escola de Direito da Universidade Diego Portales.

Unger Mangabeira, Roberto. 1976. Law in Modern Society. Nova Iorque: The Free Press.

Vargas Viancos, Juan Enrique. 1994. "Reforma Procesal Penal en América Latina: La Adecuación de las Legislaciones al Programa de los Derechos Humanos". Em Proceso penal y Derechos Fundamentales. Santiago: Corporación Nacional de Reparación y Reconciliación.

Verdugo, Mario. 1992. "Alternativas de la Reforma del Poder Judicial". Em El Poder Judicial en la Encrucijada. Estudios Acerca de la Política Judicial en Chile. Santiago: Escola de Direito da Universidade Diego Portales.

Verner G., Joel. "The Independence of the Supreme Court in Latin America: A Review of the Literature". Journal of Latin American Studies 16: 463-506.

Weyland, Kurt. 1993. "The Rise and Fall of President Collor and its Impact on Brazilian Democracy". Journal of Interamerican Studies and World Affairs 35 (1).

Wiarda J., Howard 1982. ed. Politics and Social Change in Latin America: the Distinct Tradition. Amherst, Mass: University of Massachussetts Press.

WiLSON J., Richard. 1989. "The New Legal Education in North and South America". Stanford Journal of International Law 25 (2): 375.

Zaffaroni, Eugenio Raúl. 1993. "Dimensión Política de un Poder Judicial Democrático". Boletín Comisión Andina de Juristas 37: 9-40.

Zolezzi IBÁrCEnA, Lorenzo. 1994. “Informe sobre Perú”. Em Situación y Políticas Judiciales en América Latina. Ed. Jorge Correa. Santiago: Escola de Direito da Universidade Diego Portales. 


\section{Resumo \\ Resúmen \\ Abstract}

Revista do

Serviço

Público

Ano 48

Número 1

Jan-Abr 1997

Hugo

Frühling E.

é doutor em

direito pela

Universidade

de Harvard e

é professor

do Instituto

de Ciências

Políticas da

Universidade

do Chile

Este texto refleja la necesidad de una reforma profunda en los sistemas judiciarios en los países de América Latina. El autor enumera los eventos políticos más considerables ocurridos en la región después de la decada de los 60, principalmente durante el período de los gobiernos militares, con énfasis en los modelos judiciarios prevalecientes - comunmente dependientes, manipulados y frágiles - así como en los problemas enfrentados por los jueces y funcionarios de la justicia en muchos países. Él también describe varios movimientos en pro de la reforma legal observados en dos momentos diferentes - el de fines de la década de los 60 y principios de la de los 70 y, después, durante la década de los 80 , comparando sus éxitos y fracasos y enumerando una cantidad de seguidores nacionales e internacionales. Finalmente, el lector se va a deparar con un análisis de los cambios económicos y políticos que han fomentado esta nueva preocupación por justicia y por la reforma de las instituciones legales, entre otras, en América Latina, así como las dificultades que dicho movimiento debe enfrentar en el sentido de llegar a un Estado descentralizado, eficiente y democrático. 


\section{Judicial Reform and Democratization in Latin America}

Hugo Frühling E.

This article addresses the need of a sound reform in the judiciary systems within Latin American countries. The author provides a glance of major political events held in the region after the 1960s, mainly during periods of military intervention, focusing on the profile of prevalent judicial models - likely to be dependent, manipulated and weak - as well as on problems faced by judges and judiciaries in several countries. He also describes various movements for legal reform carried out in two different moments - from the late $60 \mathrm{~s}$ and early $70 \mathrm{~s}$, and later, during the 1980s, comparing their partial successes and failures, and listing a number of international and national supporters. Finally, the reader will be presented with an analysis of political and economic changes that have fostered this new concern for justice and for the reform of legal and other institutions in Latin America, as well as the difficulties that this movement might face towards achieving decentralized, effective and democratic states. 